\title{
Acid Neutralization Capacity of a Tricalcium Silicate-Containing Calcium Phosphate Cement as an Endodontic Material
}

\section{A. Maria Cherng, Shozo Takagi, and Laurence C. Chow}

American Dental Association Foundation, Paffenbarger Research Center, MML,

National Institute of Standards and Technology, Gaithersburg, MD 20899

maria.cherng@nist.gov shozo.takagi@nist.gov laurence.chow@nist.gov

\author{
A calcium phosphate cement (CPC) was \\ shown to have the necessary attributes \\ for endodontic materials except adequate \\ basicity needed for antimicrobial \\ properties. To enhance its basicity, \\ tricalcium silicate $\left(\mathrm{Ca}_{3} \mathrm{SiO}_{5}\right)$, a highly \\ alkaline compound, was added to $\mathrm{CPC}$ \\ at a mass fraction of $0.25,0.5$ or 0.75 . The \\ basicity, acid neutralization and physical \\ properties of the $\mathrm{CPC}-\mathrm{Ca}_{3} \mathrm{SiO}_{5}$ composites \\ were investigated. Mineral trioxide \\ aggregate (MTA) was used as the control. \\ The acid neutralizing capacity of the \\ CPC- $\mathrm{Ca}_{3} \mathrm{SiO}_{5}$ composites and MTA were \\ measured by titrating the suspensions of \\ ground set samples with a $0.2 \mathrm{~mol} / \mathrm{L}$ \\ $\mathrm{HCl}$ at predetermined $\mathrm{pH}$ levels, i.e., \\ 11, 9.0, and 7.4. The setting time of \\ CPC-Ca $\mathrm{SiO}_{5}$ composites determined \\ by the Gilmore needle method was \\ $40 \pm 10 \mathrm{~min}$. Acid neutralizing capacity
}

of CPC depended $(\mathrm{p}<0.05)$ on $\mathrm{Ca}_{3} \mathrm{SiO}_{5}$ content. CPC containing $75 \% \mathrm{Ca}_{3} \mathrm{SiO}_{5}$ could neutralize slightly less acid than MTA $(\mathrm{p}<0.05)$, but it had a shorter setting time than that of MTA $(>4 \mathrm{~h})$ and excellent handling properties.

Key words: acid neutralization; basicity; calcium phosphate cement; endo-materials; mineral trioxide aggregate; setting time; tricalcium silicate.

Accepted: July 13, 2010

Available online: http://www.nist.gov/jres

\section{Introduction}

Calcium hydroxide $\left(\mathrm{Ca}(\mathrm{OH})_{2}\right)$ has been historically used as a major ingredient for pulp capping or to establish apical closure and avoid surgery in the apexification procedure [1]. The treatment requires high patient compliance, multiple appointments extending over a long period of time, and susceptibility to coronal leakage or fracture of the already thin root $[2,3]$. Mineral trioxide aggregates (MTA) is currently thought to be biocompatible [4] and effective in the above procedures. MTA, however, has relatively poor handling properties, namely very long hardening times [5], little washout resistance (no coherence) and noinjectablility. Calcium phosphate cement (CPC) [6], a mixture of equimolar amounts of tetracalcium phos- phate (TTCP) and dicalcium phosphate anhydrous (DCPA), has the above attributes needed for use in endodontic treatment, as well as good adaptation to the dentin walls and the ability to set without shrinkage. The mechanical strength of CPC is increased in saliva or plasma-like fluid [7]. In vitro [8, 9, 10], animal and clinical studies $[11,12]$ have been conducted to investigate the feasibility of using CPC for these treatments. Unmodified CPC materials do not typically have the same high alkalinity, needed for anti-microbial activity, as $\mathrm{Ca}(\mathrm{OH})_{2}$ or MTA. Tricalcium silicate $\left(\mathrm{Ca}_{3} \mathrm{SiO}_{5}\right)$ is the major component of Portland cement, which has nearly the same composition as that of MTA. Tricalcium silicate is a highly alkaline compound due to its ability to release $\mathrm{Ca}(\mathrm{OH})_{2}[13]$. In this study, various amounts of tricalcium silicate were added 
to $\mathrm{CPC}$ to enhance its basicity. $\mathrm{Ca}_{3} \mathrm{SiO}_{5}$ was selected instead of $\mathrm{Ca}(\mathrm{OH})_{2}$ because it has lower solubility. The basicity of an endodontic material can be expressed in terms of two different aspects: (1) the highest $\mathrm{pH}$ value obtainable and (2) acid neutralizing capacity. The highest obtainable $\mathrm{pH}$ value should represent the $\mathrm{pH}$ of the fluids at the surface or within the pores of the material under in vivo condition, and this value can be determined by measuring the $\mathrm{pH}$ of a physiological-like solution in contact with the material.

The acid neutralizing capacity represents the ability of the material to absorb acids produced by bacteria/inflammatory cells while holding the $\mathrm{pH}$ above a specific value. This quantity is expected to increase with decreasing $\mathrm{pH}$. For example, the material should be able to neutralize a greater amount of acid if the $\mathrm{pH}$ is allowed to drop to $\mathrm{pH} 9$ compared to $\mathrm{pH} 10$. Thus, this quantity should be expressed as a function of $\mathrm{pH}$ rather than as a single value. At the present time, none of the acid neutralizing capacity has been investigated before. Hence, the objectives of this study were to evaluate the basicity, acid neutralization capacity and physical properties of $\mathrm{CPC}-\mathrm{Ca}_{3} \mathrm{SiO}_{5}$ and MTA.

\section{Materials and Methods}

\subsection{Materials and Instruments}

CPC was made of equimolar TTCP (a mass fraction of 0.73) and DCPA (a mass fraction of 0.27). $\mathrm{Ca}_{3} \mathrm{SiO}_{5}$ was prepared using a sol gel method [14] by firing $\mathrm{CaCl}_{2}$ and tetra-ethyl ortho silicate (Sigma, St. Louis, $\mathrm{MO}) .{ }^{1}$ One hundred grams of $\mathrm{Ca}_{3} \mathrm{SiO}_{5}$ were ground in a $250 \mathrm{~mL}$ agate jar with five agate balls $(30 \mathrm{~mm}$ diameter) for six min in a ball mill (Retsch PM4, Brinkman, NY) at $200 \mathrm{rpm}$. MTA was purchased from Dentsply (Johnson City, TN). The titrant was a solution containing $0.2 \mathrm{~mol} / \mathrm{L} \mathrm{HCl}$ and $150 \mathrm{mmol} / \mathrm{L} \mathrm{NaCl}$, the latter being used as a background electrolyte. Impulsomat 614 and Dosimat 665 Titrator (Brinkman Instruments, Westbury, NY) were used in the acid titration study, and a Universal Testing Machine (United Calibration Corp., Garden Grove, CA) was used to measure diametral tensile strength (DTS). Poly-R dye (Sigma, St. Louis, MO) was used as the

\footnotetext{
${ }^{1}$ Certain commercial equipment, instruments, or materials are identified in this paper to specify the experimental procedure adequately. Such identification is not intended to imply recommendation or endorsement by the NIST or the ADAF, nor is it intended to imply that the materials or equipment identified are necessarily the best available for the purpose.
}

indicator for testing the sealing ability of CPC cement and MTA. The phase present in the set samples was identified by powder X-ray diffraction (XRD) (DMAX 2200, Rigaku Denki Co., Ltd, Woodlands, TX).

\subsection{Sample Preparation and Acid Titration / Neutralization}

The powders were prepared by combining $\mathrm{CPC}$ with a mass fraction of 0 (CPC), 0.25 (CPC-1), 0.5 (CPC-2) or 0.75 (CPC-3) of $\mathrm{Ca}_{3} \mathrm{SiO}_{5}$. The cement liquid was $0.5 \mathrm{~mol} / \mathrm{L} \mathrm{Na} \mathrm{PO}_{4}$. CPC-Ca $\mathrm{SiO}_{5}$ samples were prepared by mixing the powder and liquid at $\mathrm{P} / \mathrm{L}=2.65$ to produce pastes with good workability. MTA samples were prepared by following manufacturer's instructions $(\mathrm{P} / \mathrm{L}=3.3)$ and were used as the control. After mixing, each specimen was prepared by packing the paste into a stainless steel mold $(6 \mathrm{~mm} \mathrm{~d} \times 3 \mathrm{~mm} \mathrm{~h})$, which was subsequently covered on both the top and bottom, with two fritted glass plates (4-mm thick, $38 \%$ porosity) and incubated at $37^{\circ} \mathrm{C}$ and $100 \%$ humidity to keep the sample moist but not directly in contact with water. After $24 \mathrm{~h}$, the set sample was demolded, dried at $70^{\circ} \mathrm{C}$, and stored in a capped glass vial. For the basicity and acid neutralization capacity measurements, the set sample was ground by a mortar and pestle, and $0.2 \mathrm{~g}$ of the sample was placed in $10 \mathrm{~mL}$ of $150 \mathrm{mmol} / \mathrm{L}$ $\mathrm{NaCl}$ solution under a $\mathrm{N}_{2}$ atmosphere (to prevent atmospheric $\mathrm{CO}_{2}$ incorporation) at $37^{\circ} \mathrm{C}$. A flat end combination $\mathrm{pH}$ electrode (Thomas Scientific, model \# S450CBNC, Swedesboro, NJ, USA) was connected to a $\mathrm{pH}$ meter/titrator, and the $\mathrm{pH}$ was measured continuously to determine the highest $\mathrm{pH}$ obtainable. The sample suspension was under constant stirring $(350 \mathrm{rpm})$ and the $\mathrm{pH}$ of the solution was monitored. The standard uncertainty of the $\mathrm{pH}$ measurement was estimated to be $0.01 \mathrm{pH}$ unit.

After the maximum $\mathrm{pH}$ was recorded, $0.2 \mathrm{~mol} / \mathrm{L}$ $\mathrm{HCl}$ in $150 \mathrm{mmol} / \mathrm{L} \mathrm{NaCl}$ solution was added to reduce the $\mathrm{pH}$ to predetermined levels (9.0 and 7.4), and the amount of acid titrated (consumed) in order to reach each of the levels was recorded. The data would be presented as $\mathrm{mEq}$ of acid neutralized per unit mass of the test sample as a function of $\mathrm{pH}$. The standard uncertainty of the acid neutralization capacity measurement was estimated to be $0.02 \mathrm{mEq} \mathrm{acid} / \mathrm{g}$ of sample.

\subsection{Setting Time and Mechanical Strength}

The setting time of each type of material was determined using the Gilmore needle method [15]. Diametral tensile strength (DTS) was used as a measurement of mechanical strength of the materials. For DTS measurements, each set sample was prepared as 
described above, placed in $1 \mathrm{~mL}$ of distilled water and incubated at $37^{\circ} \mathrm{C}$ and $100 \%$ relative humidity for $24 \mathrm{~h}$. The DTS of the wet set samples $(6 \mathrm{~mm} \mathrm{~d} \times 3 \mathrm{~mm} \mathrm{~h})$ were measured using a Universal Testing Machine, as previously described [16]. The standard uncertainty of the acid neutralization capacity measurement was estimated to be the standard deviation of the measurement.

\subsection{Phase Composition Characterizations}

Set samples of CPC, CPC-1, CPC-2, CPC-3, and MTA both before and after titration experiments were also characterized by powder x-ray diffraction (XRD) to determine the phase composition.

\subsection{Sealing Ability Tests}

Sealing abilities of wet set samples of CPC, CPC-1, CPC-2 and CPC-3, $\mathrm{Ca}_{3} \mathrm{SiO}_{5}$ and MTA before titration were estimated by $1 \%$ Poly-R dye penetration test [17]. The standard uncertainty of the dye penetration measurements was estimated to be $0.1 \mathrm{~mm}$ based on the uncertainty of the measuring ruler.

\subsection{Statistical Analysis}

ANOVA and Newman-Keuls multiple comparison tests were performed to analyze the setting time, DTS, and acid neutralization capacity data.

\section{Results}

The setting times (mean \pm s.d.; $\mathrm{n}=3$ ) for $\mathrm{CPC}$, CPC-1, and CPC-2 were $30 \pm 3$ min which were not significantly different $(\mathrm{p}>0.05)$ but significantly shorter $(\mathrm{p}<0.05)$ than that of CPC-3 $(50 \pm 5 \mathrm{~min})$. However, CPC-3 had a significantly shorter setting time than that of MTA $(240 \pm 30 \mathrm{~min})$. The DTS (mean \pm s.d.; $\mathrm{n}=6$ ) for CPC, CPC-1, CPC-2, CPC-3 were $5.38 \pm 0.75, \quad 3.74 \pm 0.57, \quad 4.79 \pm 0.34$, and $5.17 \pm 0.56$ respectively, which were not significantly different $(\mathrm{p}>0.05)$ yet lower than that of MTA (13.37 \pm 0.23$)$.

The highest obtainable $\mathrm{pH}$ and the amounts of $\mathrm{HCl}$ consumed (in $\mathrm{mEq} / \mathrm{g}$ of sample) for $\mathrm{CPC}, \mathrm{CPC}-1$, CPC-2, CPC-3 and MTA (mean \pm s.d.; $\mathrm{n}=3$ ) are shown in Table 1. The dye penetration test of CPC, CPC-1, CPC-2, CPC-3 (P/L = 2.65), $\mathrm{Ca}_{3} \mathrm{SiO}_{5}$ and MTA (mean \pm s.d.; $\mathrm{n}=2$ ) indicated that the depth of penetration by measurement was completely penetrated, $0.2 \pm 0.1,0.1 \pm 0.1,<0.1,<0.1$ and $<0.1 \mathrm{~mm}$ respectively. Powder x-ray diffraction patterns of the CPC mixtures and MTA both before (Fig. 1 and Fig. 3) and after (Fig. 2 and Fig. 3) the titration revealed the presence of $\mathrm{Ca}(\mathrm{OH})_{2}$, which was largely consumed after acid neutralization.

Table 1. Acid neutralization capacity of CPC, CPC-1, CPC-2, CPC-3 and MTA

\begin{tabular}{|c|c|c|c|c|c|}
\hline & $\mathrm{CPC}$ & CPC-1 & CPC-2 & CPC-3 & MTA \\
\hline $\begin{array}{l}\text { Highest } \\
\text { obtainable } \mathrm{pH}\end{array}$ & $9.32 \pm 0.04$ & $11.54 \pm 0.07$ & $\begin{array}{l}12.07 \pm 0.05 \\
* \quad\end{array}$ & $12.23 \pm 0.14$ & $12.13 \pm 0.09$ \\
\hline $\begin{array}{l}\text { Acid neutralizing } \\
\text { capacity (to } \mathrm{pH} \\
11.00) \mathrm{mL}\end{array}$ & No titration & $0.51 \pm 0.09$ & $2.89 \pm 0.24$ & $\begin{array}{l}4.89 \pm 0.72 \\
* \quad\end{array}$ & $4.59 \pm 0.28$ \\
\hline $\begin{array}{l}\text { Acid neutralizing } \\
\text { capacity (to } \mathrm{pH} \\
\text { 9.00) } \mathrm{mL}\end{array}$ & $0.12 \pm 0.03$ & $1.64 \pm 0.30$ & $6.29 \pm 0.60$ & $9.00 \pm 1.02$ & $11.43 \pm 0.96$ \\
\hline $\begin{array}{l}\text { Acid neutralizing } \\
\text { capacity (to } \mathrm{pH} \\
\text { 7.40) } \mathrm{mL}\end{array}$ & $0.78 \pm 0.05$ & $4.11 \pm 0.26$ & $9.40 \pm 0.96$ & $13.42 \pm 0.86$ & $15.19 \pm 1.04$ \\
\hline
\end{tabular}

\footnotetext{
*Values connected by a line were not significantly different $(\mathrm{p}>0.05)$.
} 


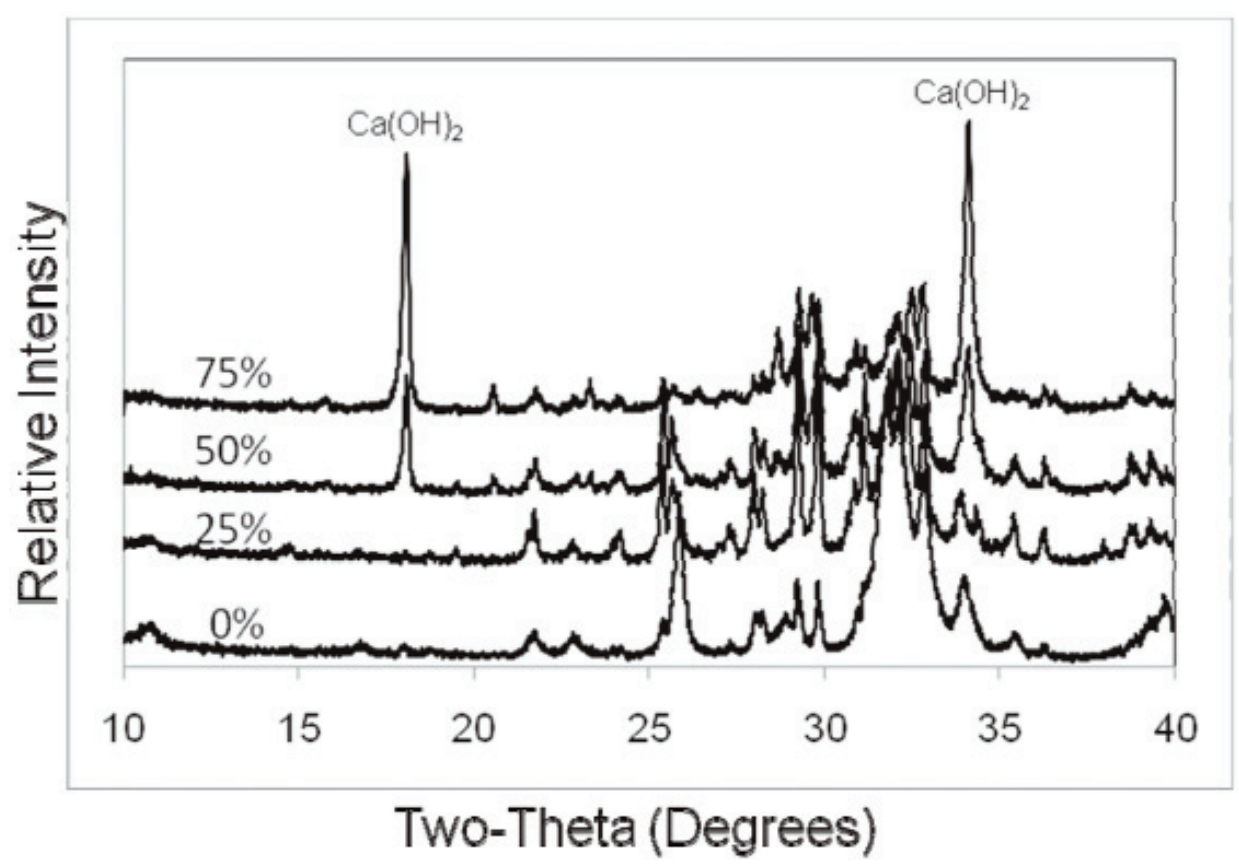

Fig. 1. XRD patterns of CPC, CPC-1, CPC-2 and CPC-3 before titration.

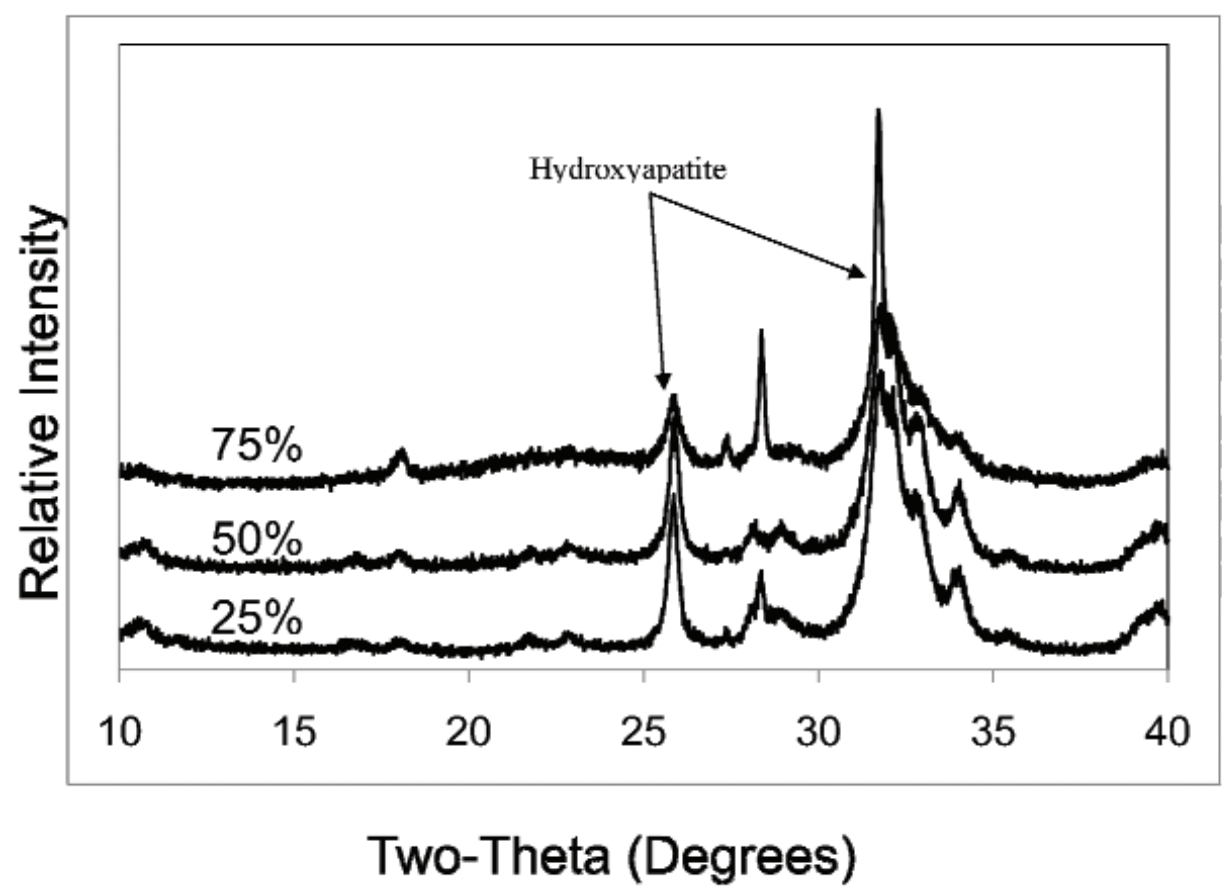

Fig. 2. XRD patterns of CPC-1, CPC-2, CPC-3 after titration with $0.2 \mathrm{~mol} / \mathrm{L} \mathrm{HCl}$. 


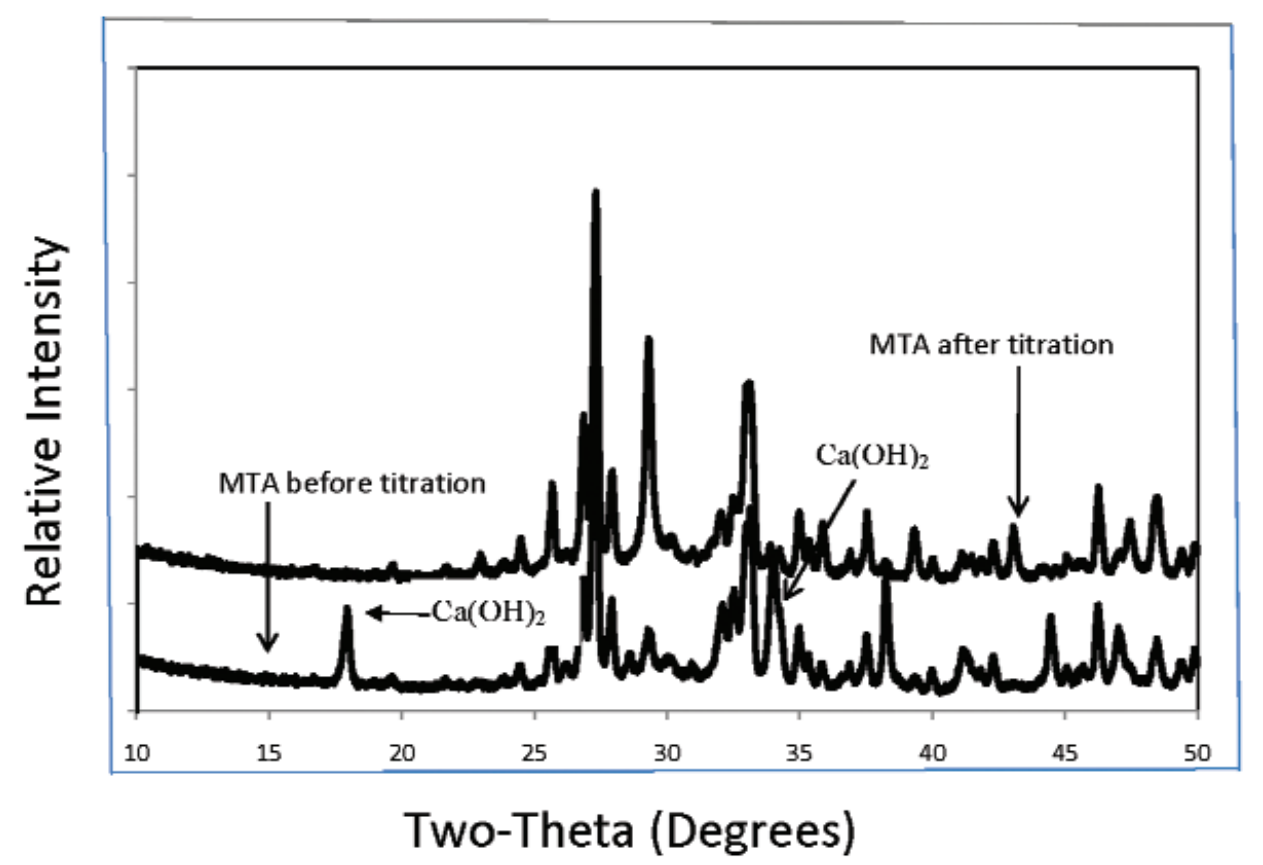

Fig. 3. XRD patterns of MTA before and after titration with $0.2 \mathrm{~mol} / \mathrm{L} \mathrm{HCl}$.

\section{Discussion}

In this study, $\mathrm{Ca}_{3} \mathrm{SiO}_{5}$ was used as an alkaline additive instead of $\mathrm{Ca}(\mathrm{OH})_{2}$ because it dissolves more slowly and can improve the sealing ability of $\mathrm{CPC}$ as a filler. MTA contains bases $\left(\mathrm{Ca}_{2} \mathrm{SiO}_{4}, \mathrm{Ca}_{3} \mathrm{Al}_{2} \mathrm{O}_{6}\right)$ other than $\mathrm{Ca}_{3} \mathrm{SiO}_{5}$ that may contribute to the higher acid neutralizing capacity at the levels of $\mathrm{pH} 9$ and $7.4(p>0.05)$. Acid neutralizing capacity of the CPC- $\mathrm{Ca}_{3} \mathrm{SiO}_{5}$ composites depended strongly $(\mathrm{p}<0.05)$ on the $\mathrm{Ca}_{3} \mathrm{SiO}_{5}$ content. CPC-3 ( $75 \% \mathrm{Ca}_{3} \mathrm{SiO}_{5}$ content) also had a relatively high neutralization capacity $(\mathrm{p}>0.05)$, although MTA could neutralize more acid.

Basicity has been related to the antimicrobial property of endodontic materials. The capacity of acid neutralization by the material at different $\mathrm{pHs}$ should be an important property, but it has not been adequately addressed at the present time. There is neither a pre-set highest obtainable $\mathrm{pH}$ value nor a minimum acid neutralization capacity at a particular $\mathrm{pH}$ that has been established as the requirement for the antimicrobial activity. However, by combining different amounts of $\mathrm{Ca}_{3} \mathrm{SiO}_{5}$ with $\mathrm{CPC}$, we can design $\mathrm{CPC}$ at different alkaline $\mathrm{pHs}$ if it is required.

The $\mathrm{CPC}-\mathrm{Ca}_{3} \mathrm{SiO}_{5}$ samples had lower DTS (4.79 $\mathrm{MPa})$ than MTA (13.3 MPa), likely due to the lower
$\mathrm{P} / \mathrm{L}$ ratio. However, in the area of endodontic application, strength is not as critical as that of restorative materials.

Powder XRD patterns of the CPC mixtures indicated the formation of hydroxyapatite which was found to adapt to the contours of the dentin surfaces at a microscopic levels. XRD also showed the level of $\mathrm{Ca}(\mathrm{OH})_{2}$ in $\mathrm{CPC}-\mathrm{Ca}_{3} \mathrm{SiO}_{5}$ mixtures corresponding with the mass fraction of $\mathrm{Ca}_{3} \mathrm{SiO}_{5}$.

MTA samples prepared by following manufacturer's instruction had a much longer setting time $(4 \mathrm{~h})$ than that of $\mathrm{CPC}-\mathrm{Ca}_{3} \mathrm{SiO}_{5}$ samples (30 $\mathrm{min}$ to $50 \mathrm{~min}$ ).

Although the $\mathrm{P} / \mathrm{L}$ ratio used for the preparation of CPC-Ca $\mathrm{SiO}_{5}$ samples was lower than that of MTA, it still provided an equally good seal against dye penetration and had good coherency and better handling properties than MTA.

\section{Acknowledgements}

Tricalcium silicate was prepared by Stan Frukhtbeyn in the laboratory. This work has been supported by the American Dental Association Foundation, the National Institute of Standards and Technology, and the National Institute of Dental and Craniofacial Research (DE11789). 


\section{References}

[1] A. Frank, Therapy for the divergent pulpless tooth by continued apical formation, J. Am. Dent. Ass. 72, 87-93 (1966).

[2] J. A. Weisenseel, Jr., M. L. Hicks, G. B. Pelleu, Jr., Calcium hydroxide as an apical barrier, J. Endod 13, 1-5 (1987).

[3] J. W. Schumacher, R. E. Rutledge, An alternative to apexification, J. Endod 19, 529-531 (1993).

[4] C. H. Hauman and R. M. Love, Biocompatibility of dental materials used in contemporary endodontic therapy. A review. Part 2, root-canal filling materials, Int. Endod J. 36, 147-160 (2003).

[5] R. S. Schwartz, M. Mauger, D. J. Clement, and W. A. Walker, Mineral trioxide aggregate: A new material for endodontics, J. Am. Dent. Assoc. 130, 967-975 (1999).

[6] W. E. Brown and L. C. Chow, A new calcium phosphate cement, Cem. Res. Prog. 1987, 352-79 (1986).

[7] K. Ishikawa, S. Takagi, L. C. Chow, Y. Ishikawa, E. D. Eanes, and K. Asaoka, Behavior of a calcium phosphate cement in simulated blood plasma in vitro, Dent. Mater. 10, 26-32 (1994).

[8] A. Sugawara, L. C. Chow, S. Takagi, and H. Chohayeb, An in vitro evaluation of sealing ability of a calcium phosphate cement when used as a root canal sealer-filler, J. Endod 16, 162-165 (1990).

[9] G. G. Goodell, T. O. Mork, J. W. Hutter, and B. K. Nicoll, Linear dye penetration of a calcium phosphate cement apical barrier, J. Endod 23, 174-177 (1997).

[10] J. Chau, J. W. Hutter, T. O. Mork, and B. K. Nicoll, An in vitro study of furcation perforation repair using calcium phosphate cement, J. Endod 23, 588-592 (1997)

[11] A. A. Chohayeb, L. C. Chow, and P. J. Tsaknis, Evaluation of calcium phosphate as a root canal sealer-filler material, J. Endod 13, 384-387 (1987).

[12] Y. C. Hong, J. T. Wang, C. Y. Hong, W. Brown, and L. C. Chow, The periapical tissue reaction to calcium phosphate cement in the teeth of monkeys, J. Biomed. Mater. Res. 25, 485-498 (1991).

[13] V. K. Peterson, D. A. Neumann, and R. A. Livingston, Inelastic neutron scattering investigation of hydrating tricalcium and dicalcium silicate mixture pastes: $\mathrm{Ca}(\mathrm{OH})_{2}$ formation and evolution of strength, J. Mater. Res. 21, 1836-1842 (2006).

[14] W. Y. Zhao and J. Chang, Sol-gel synthesis and in vitro bioactivity of tricalcium silicate powders, Mater. Lett. 58, 23502353 (2004).

[15] ASTM Standard test method for time of setting of hydraulic cement paste by Gilmore needles, ASTM International Standard C, 266-299 (2002).

[16] A. Cherng, S. Takagi, and L. C. Chow, Effects of hydroxypropyl methylcellulose and other gelling agents on the handling properties of calcium phosphate cement, J. Biomed. Mater. Res. 35, 273-277 (1996).

[17] A. Cherng, L. C. Chow, and S. Takagi, In vitro evaluation of a calcium phosphate cement root canal filler/sealer, J. Endo 27, 613-615 (2001).
About the authors: A. Maria Cherng is a dentist/ chemist, Shozo Takagi is a senior project leader and Laurence Chow is a chief research scientist with the Paffenbarger Research Center. American Dental Association Foundation at NIST. The National Institute of Standards and Technology is an agency of the U.S. Department of Commerce. 